Revista da Sociedade Brasileira de Medicina Tropical

Journal of the Brazilian Society of Tropical Medicine

Vol.:52:e20190226: 2019

doi: 10.1590/0037-8682-0226-2019

\title{
Editorial
}

\section{West Nile virus infection in Brazil}

\author{
Luiz Tadeu Moraes Figueiredo ${ }^{[1]}$
}

[1]. Centro de Pesquisa em Virologia, Faculdade de Medicina de Ribeirão Preto, Universidade de São Paulo, Ribeirão Preto, SP, Brasil.

The West Nile virus (WNV) is an arbovirus of the Flavivirus genus (Flaviviridae) that occurs in Africa and in the Mediterranean basin, infects birds, and is transmitted by Culicidae mosquitoes. In the last 20 years, after an unexpected introduction into the American continent, WNV rapidly became an important public health problem, particularly in North America where it has caused infections of the central nervous system in thousands of humans, with many deaths. Introduced into North America in 1998, probably by an infected and viremic passenger coming from Israel, WNV arrived in the City of New York $^{1}$. It is surprising how rapidly WNV adapted to a cycle involving American mosquitoes and birds. By doing so, the virus caused an epizootic that killed many birds, affected humans and horses, and spread all around North America within a few years.

The epizootic among birds caused by WNV also spread southward reaching the Caribbean and Central and South America where it also infected horses. These animals were found with antibodies to WNV in Colombia and the virus was isolated from a horse in Argentina in 2006 2,3 . In Brazil, neutralizing antibodies to WNV were reported in horses from the Pantanal and the Northeast regions of Brazil ${ }^{4}$. However, only in 2014, the first case of WNV encephalitis was reported in the Northeast region, State of Piaui ${ }^{5}$. The infected patient had encephalitis with flaccid paralysis and survived. Animal reservoirs and vectors of WNV related to this human case remain unknown. Finally, the virus was isolated last year from a horse in Espírito Santo State, southeast of Brazil ${ }^{6}$. Thus, despite evidence of WNV circulating in Brazil for at least 8 years, only one human case has been reported.

Why do we not have human WNV outbreaks in Brazil? The circulation of many flaviviruses in the country could explain this phenomenon. Brazil has some endemic American flaviviruses such as Saint Louis encephalitis virus, Cacipacore, Ilhéus, and Bussuquara viruses that cause sporadic

Corresponding Author: Luiz Tadeu Moraes Figueiredo.

e-mail: ltmfigue@fmrp.usp.br

Orcid: 0000-0002-6800-6076

Received 3 May 2019

Accepted 9 May 2019 human cases, and even Rocio virus that cause outbreaks ${ }^{7}$. Saint Louis encephalitis, Cacipacore, and Rocio virus are phylogenetically closely related to $\mathrm{WNV}$, infect birds, and are transmitted by Culicidae mosquitoes. In Brazil, some imported flaviviruses also became serious public health problems: dengue viruses 1-4, Zika virus, and yellow fever virus, all transmitted by Aedes aegypti and causing large outbreaks in the last five years ${ }^{8}$. Finally, we have the attenuated virus vaccine to yellow fever that has been extensively used to immunize most of the Brazilian population. Therefore, it is possible that infections caused by other flaviviruses could induce some level of crossprotection to infections or disease caused by WNV. This cross-protection could prevent more cases of encephalitis and outbreaks due to WNV. Another possible explanation could be related to genomic mutations leading to a lower virulence of the South American WNV. However, it has not been confirmed by a phylogenetic analysis of the Brazilian strain of WNV. The virus was more closely related to two strains isolated from birds, Corvus brachyrhynchos in 2002 and Pelecanus erythrorhynchos in 2005, both from the United States. A 99.0\% (nucleotide) and 99.6\% (amino acid) identity was observed between the Brazilian WNV and North American isolates ${ }^{6}$.

Despite the supposed apparent protection induced by antibodies of other flaviviruses or differences among viruses, it is important to consider WNV as a serious threat to human and veterinarian public health in Brazil. It is also important to remember that there is no human vaccine or antiviral drug routinely used for the treatment of WNV disease. Besides, mutations or introduction of more virulent WNV strains in Brazil could lead to outbreaks involving this virus. It is also important to consider that eventual outbreaks of WNV infection in human populations of remote areas of the country may not be detected by the public health system. Therefore, surveillance of WNV must be implemented based on monitoring and diagnosis of viral infections of the central nervous system, and also promoting virus detection or determining the levels of antibodies to the virus in humans, horses, and birds. You can find in this edition of the RSBMT an interesting review on West Nile virus infection in Brazil. West Nile virus infections are here! Are we prepared to face another Flavivirus epidemic? 


\section{Conflict of interest}

The author declares that there is no conflict of interest.

\section{REFERENCES}

1. Nash D, Mostashari F, Fine A, Miller J, O'Leary D, Murray K, et al. The Outbreak of West Nile Virus Infection in the New York City Area in 1999. N Engl J Med. 2001;344(24):1807-14.

2. Mattar S, Edwards E, Laguado J, González M, Alvarez J, Komar N. West Nile virus antibodies in Colombian horses. Emerg Infect Dis. 2005;11(9):1497-8.

3. Morales MA, Barrandeguy M, Fabbri C, Garcia JB, Vissani A, Trono K, Gutierrez G, Pigretti S, Menchaca H, Garrido N, Taylor $\mathrm{N}$, Fernandez F, Levis S, Enría D. West Nile virus isolation from equines in Argentina, 2006. Emerg Infect Dis. 2006;12(10): 1559-61.

4. Silva JR, de Medeiros LC, dos Reis VP, Chávez JH, Munhoz TD, Borges GP, et al. Serologic survey of West Nile virus in horses from Central-West, Northeast and Southeast Brazil. Mem Inst Oswaldo Cruz. 2013;108(7):921-3.

5. Vieira MACS, Romano APM, Borba AS, Silva EVP, Chiang JO, Eulálio KD, et al. West Nile Virus Encephalitis: The First Human Case Recorded in Brazil. Am J Trop Med Hyg. 2015;93(2):377-9.

6. Martins LC, da Silva EVP, Casseb LMN, da Silva SP, Cruz ACR, Pantoja JAS. First isolation of West Nile virus in Brazil. Mem Inst Oswaldo Cruz. 2018;1-19.

7. Figueiredo LTM. The Brazilian Flaviviruses. Microbes and Infection. 2000;2(13):1643-9.

8. Figueiredo LTM. How are so many foreign arboviruses introduced into Brazil? Rev Soc Bras Med Trop. 2016;49(6):665-7. 